\title{
Humas Kominfo Dalam Mencegah Bahaya Radikalisme Di Media Sosial
}

\author{
Jefri Handoko, Eko Harry Susanto, \\ Jefri.915150009@stu.untar.ac.id.ekos@fikom.untar.ac.id
}

Fakultas Ilmu Komunikasi Universitas Tarumanagara

\begin{abstract}
This research talk about public relations ministry of communications and information in preventing radicalism danger in social media. The result of this research is to know the development of radicalism in social media, the role performed by public relations communication and information in preventing danger radicalism in social media and the obstacles facing implement this role. The theory used in this research is the, radicalism the role of public relations, the types of communications and public relations barriers. The research was conducted using a qualitative methodology by explaining findings. Data collection method of this research is, interview, observation and documentary. Interviews and observation done to 7 of resource person who ever read and understand about radicalism occuring in social media.
\end{abstract}

Keywords: Radicalism, The Role of Public Relations, Ministry of Communication and Information, The Obstacles of Public Relations

\begin{abstract}
Abstrak
Penelitian ini membahas tentang humas atau public relations Kementerian Komunikasi dan Informatika (KemKominfo) dalam mencegah bahaya radikalisme di media sosial. Hasil dari penelitian ini ialah untuk mengetahui perkembangan radikalisme di media sosial, peran yang dilakukan oleh humas Kominfo dalam mencegah bahaya radikalisme di media sosial dan hambatan-hambatan yang dihadapi melaksanakan peran tersebut. Teori yang digunakan dalam penelitian ini adalah teori radikalisme, peran humas, jenis-jenis komunikasi dan hambatanhambatan humas. Penelitian ini dilakukan dengan metode kualitatif dengan menjelaskan hasil temuan. Metode pengumpulan data dari penelitian ini adalah wawancara, observasi, dan mendokumentasikan. Wawancara dan observasi dilakukan kepada 7 narasumber yang pernah membaca dan mengerti mengenai radikalisme yang terjadi di media sosial.
\end{abstract}

Kata Kunci: Radikalisme, Peran Humas, Kementerian Komunikasi dan Informatika, Hambatan-hambatan Humas.

\section{Pendahuluan}

Pada zaman yang serba modern seperti pada saat ini, kita diberi kemudahan dalam mengakses berbagai informasi melalui internet di mana saja dan kapan saja. Bahkan, internet bukanlah barang yang mahal, karena dampak dari pembangunan yang semakin maju memudahkan kita untuk mengakses Internet.

Pada bulan Januari 2019 Wearesosial Hootsuite mengeluarkan hasil riset bahwa pengguna media sosial di Indonesia telah mencapai 150 juta atau sebesar 56\% dari total populasi, jumlah ini meningkat $20 \%$ dari survei sebelumnya. Sedangkan media sosial user yang menggunakan mobile (gadget) mencapai 130 juta, jumlah ini setara dengan $48 \%$ dari jumlah populasi penduduk di Indonesia (https://databoks.katadata.co.id/datapublish/2019/02/08/berapa-pengguna-media- 
sosial-indonesia diakses pada tanggal 27 Februari 2019 Pukul 14.30 WIB). Seiring pertumbuhan media sosial ini, bahkan menjadi akar masalah dari perkara yang terjadi belakangan ini, hal yang dimaksud ini adalah mengenai persatuan bangsa. Karena melalui media sosial banyak kalangan yang justru tidak bijak dalam menggunakan media sosial untuk menebar kebencian, hujatan, hasutan, informasi hoax, serta paham radikal.

Indonesia merupakan negara demokrasi yang cukup liberal dimana setiap warganya diberikan kebebasan untuk berpendapat dan saking bebasnya dan liberalnya banyak masyarakat yang menyalahgunakan hak kebebasan tersebut. Dimana kita melihat pada saat ini banyak masyarakat yang bebas melontarkan provokasi, celaan, hujatan dan ujaran kebencian. Kebebasan yang terjadi saat ini justru membuat masyarakat tidak ingin diatur apalagi menaati peraturan, seolah-olah peraturan dibuat untuk dilanggar.

Akhir-akhir ini isu tentang agama semakin menonjol. Namun, isu agama yang muncul bukan yang kelihatannya damai, sejuk dan toleran sebagaimana tujuan dari agama itu sendiri, melainkan justru bersifat keras, memaksa, dan intoleran.

Inilah yang mengakibatkan paham-paham garis keras atau radikal tumbuh subur di Indonesia. Amat memprihatinkan, kebebasan di negara kita yang tidak disertakan dengan pengetahuan menjadi lahan subur bagi paham radikal.

Radikalisme merupakan paham yang menginginkan adanya perubahan/pergantian terhadap suatu paham di masyarakat sampai ke akar-akarnya, bahkan memaksa dengan melakukan cara-cara kekerasan. Tidak hanya itu kelompok radikal ini juga menghendaki perubahan sepenuhnya terhadap semua aspek di kehidupan masyarakat dan juga kondisi dimasyarakat. Terdapat beberapa indikator yang terbilang sikap radikalisme yaitu yang pertama intoleran, kedua fanatik, ketiga selalu menganggap dirinya benar dan yang lain salah, keempat membedakan diri dari kelompok umat islam pada umumnya dan kelima dalam mencapai suatu tujuan kelompok ini menggunakan cara-cara kekerasan (BNPT, 2016).

Seiring dengan berkembangnya teknologi, keberadaan media sosial merupakan bagian terpenting di kehidupan masyarakat yang tujuannya menggali, maupun memperoleh informasi yang dibutuhkan. Kelompok radikalisme maupun terorisme ini memanfaatkan media sosial sebagai salah satu alat atau platform untuk menyebarkan paham mereka.

Dampak dari tindakan itu menimbulkan keresahan seperti situasi yang mencekam, timbul perasaan yang cemas dan takut, timbul rasa di teror yang memakan banyak korban. Maka dari itu diperlukan tindakan pengendalian sosial yang dilakukan oleh pemerintah atau lembaga-lembaga pemerintah untuk mencegah dan mengurangi kemungkinan terjadinya hal yang tidak diinginkan di masa yang akan datang hal ini juga disebut preventif dimana pemerintah dan juga lembaga-lembaga pemerintah lainnya bertugas dalam melakukan pencegahan tindakan serta paham radikalisme maupun terorisme.

Pada tahun 2018, sebanyak 295 situs telah diblokir oleh Kementerian Kominfo dimana situs yang diblokir ini mengandung konten terorisme dan radikalisme. Tidak hanya di tahun 2018 namun sejak 2010 hingga saat ini Kementerian Kominfo telah melakukan pemblokiran situs yang bermuatan konten terorisme dan radikalisme ini. Lebih lanjut, Kominfo menyebut, kebanyakan situs yang diblokir berasal dari luar negeri dengan domain registrasi dot com (Wahyunanda Kusuma Pertiwi, 2018). 
Berdasarkan latar belakang yang telah penulis jelaskan, maka penulis ingin melakukan penelitian dengan judul "Humas Kominfo Dalam Mencegah Bahaya Radikalisme di Media Sosial”.

\section{Metode Penelitian}

Didalam buku Moleong mengatakan bahwa pendekatan penelitian kualitatif yaitu penelitian yang memahami fenomena tentang apa yang telah dirasakan atau dialami oleh subjek penelitian, seperti persepsi, motivasi, tindakan, perilaku, dan lainnya secara holistik dengan mendeskripsikan kata-kata dan bahasa di dalam suatu konteks yang khusus dan alamiah dengan menggunakan beberapa metode alami, maka dari itu peneliti menggunakan pendekatan penelitian kualitatif (Moleong, 2009: 6).

Jenis penelitian deskriptif digunakan dalam penelitian ini. Deskriptif merupakan sebuah metode untuk meneliti status kelompok manusia, objek, set kondisi, cara pemikiran, ataupun kelas peristiwa di masa sekarang (Nazir, 2011: 54).

Pada penelitian ini penulis menggunakan metode pengumpulan data wawancara mendalam sebagai data primer dan penelusuran data online sebagai data sekunder.

Muri Yusuf menegaskan penelitian kualitatif, wawancara adalah suatu proses interaksi antara pewawancara dengan orang yang diwawancarai melalui komunikasi tatap muka atau langsung (Yusuf, 2014: 372).

Dalam penelitian ini penulis juga melakukan pencarian data melalui online, berupa jurnal ilmiah dan informasi melalui berita online. Penulis menggunakan jaringan internet untuk mengakses dan mencari informasi berbasis digital.

Metode penelusuran data online yang dimaksud yaitu melakukan penelusuran melalui media online seperti internet dengan memanfaatkan data informasi online dengan mudah (Bungin, 2010: 124-125).

\section{Hasil Temuan}

Berikut ini penulis akan paparkan beberapa sub-pembahasan dari temuan dan hasil yang telah penulis peroleh:

\section{Radikalisme di Media Sosial}

Di tengah perkembangan teknologi yang semakin modern, demikian juga dengan pertumbuhan media sosial yang semakin cepat, justru ini menjadi akar dari permasalahan yang terjadi belakangan ini. Hal yang dimaksud ini adalah mengenai persatuan bangsa, karena banyak kalangan yang menyalahgunakan media sosial ini untuk menebar ujaran kebencian, hujatan, hasutan, informasi hoax, serta paham radikal.

Inilah yang mengakibatkan paham-paham garis keras atau radikal tumbuh subur di Indonesia. Amat memprihatinkan dan menimbulkan keresahan, kebebasan di negara kita yang tidak disertakan dengan pengetahuan menjadi lahan subur bagi paham radikal. 


\begin{tabular}{c|l} 
Jenis Kegiatan & \multicolumn{1}{|c}{ Tabel 1 Radikalisme Di Media Sosial } \\
\hline Isu Radikalisme & $\begin{array}{l}\text { Berdasarkan survey yang ditunjukkan banyak } \\
\text { masyarakat yang terpapar dengan isu radikalisme ini } \\
\text { seiring denga era digital yang bertumbuh pesat, dimana } \\
\text { kelompok radikal ini menyerukan kekerasan. }\end{array}$ \\
\hline $\begin{array}{c}\text { Sasaran } \\
\text { Radikalisme }\end{array}$ & $\begin{array}{l}\text { Kurangnya perhatian dari orang tua yang bisa dikatakan } \\
\text { pasif dalam melakukan didikan terhadap anak yang } \\
\text { tergolong remaja, sehingga dapat menjadi sasaran dari } \\
\text { para penebar kebencian dan radikalisme ini. }\end{array}$ \\
\hline Radikalisme dan & $\begin{array}{l}\text { Radikalisme lumayan berkembang dibandingkan tahun- } \\
\text { Perpecahannya sebelumnya seperti adanya fenomena yang terjadi } \\
\text { di twitter dimana para user yang sudah memulai } \\
\text { meretweet konten-konten yang berbau radikalisme yang } \\
\text { dapat melahirkan timbulnya perpecahan. }\end{array}$
\end{tabular}

Sumber: Diolah oleh peneliti

Beberapa pendapat yang telah narasumber kemukakan mengenai radikalisme di media sosial saat ini lumayan berkembang dibandingkan tahun-tahun sebelumnya, karena era digital yang tumbuh cukup pesat, dan anak remaja merupakan sasaran utama bagi para kelompok radikal ini untuk menyerukan kekerasan.

Radikalisme di Media Sosial saat ini memang cukup meresahkan dimana kelompok radikal ini bergerak cukup masif di media sosial dengan berbagai platform sehingga menimbulkan banyak teror dari kelompok-kelompok radikal ini.

\section{Upaya Mencegah Bahaya Radikalisme di Media Sosial}

Seiring berkembangnya radikalisme di Indonesia terutama yang terjadi di media sosial, banyak sekali upaya yang dilakukan oleh pemerintah untuk mencegah berkembangnya radikalisme ini agar masyarakat tidak terpapar paham radikalisme yang terjadi di media social, berikut ini adalah upaya yang dilakukan pemerintah dalam mencegah bahaya radikalisme di media sosial:

\begin{tabular}{c|l}
\multicolumn{1}{c}{ Tabel 2 Upaya Mencegah Bahaya Radikalisme di Media Sosial } \\
Keterangan & \multicolumn{1}{c}{ Penjelasan } \\
\hline $\begin{array}{c}\text { Peran Humas } \\
\text { Kominfo }\end{array}$ & $\begin{array}{l}\text { Secara garis besar bahwa Kominfo telah melakukan } \\
\text { edukasi terhadap masyarakat secara masif dimana } \\
\text { Kominfo mengadakan seminar, menyebar tagline yang } \\
\text { memuat konten positif, bahkan tidak hanya di } \\
\text { lingkungan Jakarta namun di semua bagian Indonesia } \\
\text { dengan bekerjasama dengan Dinas Kominfo setempat }\end{array}$ \\
\hline $\begin{array}{c}\text { Peran Relawan } \\
\text { dari masyarakat }\end{array}$ & $\begin{array}{l}\text { Banyak peran dari organisasi dan komunitas sekitar yang } \\
\text { juga turut serta untuk meng-counter narasi-narasi yang }\end{array}$
\end{tabular}


berbau paham radikalisme dan terorisme, agar masyarakat tidak terdoktrin dengan paham tersebut.

Sumber: Diolah oleh Peneliti

Pemerintah memberikan upaya yang lebih dalam mencegah radikalisme ini berkembang di Indonesia, seperti yang dijelaskan diatas bahwa Pemerintah juga menciptakan sebuah Crawling Engine yang berfungsi untuk mengsaring setiap kontenkonten negatif untuk ditindak lanjuti.

Tidak hanya seorang Tokoh Agama namun berbagai influencer juga dapat memberikan pengaruh untuk mengkampanyekan pencegahan radikalisme ini.

Penjelasan diatas membuktikan bahwa upaya pemerintah dan juga relawan dalam mencegah bahaya radikalisme ini sangat serius dilakukan yang tujuannya agar radikalisme ini dapat hilang sepenuhnya dari Indonesia, dan menanamkan rasa kemanusiaan kepada setiap masyarakat di Indonesia.

3. Hambatan-hambatan yang dihadapi

Berbagai tantangan dan hambatan juga dihadapi dan dialami oleh pemerintah dan juga relawan dalam mengedukasi masyarakat :

Tabel 3 Pernyataan Terhadap Hambatan-Hambatan yang di Hadapi

\begin{tabular}{c|l} 
Pernyataan & \multicolumn{1}{|c}{ Alasan } \\
\hline $\begin{array}{c}\text { Hambatan-hambatan } \\
\text { Kominfo mengedukasi } \\
\text { masyarakat akan bahaya } \\
\text { besar bahwa adalah dari pihak-pihak ormas. } \\
\text { Namun masyarakat sendiri juga bisa menjadi } \\
\text { hambatan dimana kurannya awareness untuk } \\
\text { meng-counter radikalisme, seperti } \\
\text { membagikan konten-konten yang positif yang } \\
\text { tujuannya untuk menyuarakan nilai-nilai } \\
\text { Pancasila agar tidak terpapar paham } \\
\text { radikalisme. }\end{array}$ \\
$\begin{array}{c}\text { Hambatan lainnya yang } \\
\text { dihadapi oleh relawan seperti } \\
\text { Influencer maupun Tokoh- } \\
\text { Tokoh penting. }\end{array}$ & $\begin{array}{l}\text { Masyarakat Indonesia harus lebih aware } \\
\text { radikalisme dan bekal dasar pengetahuan } \\
\text { tentang agama yang mengajarkan kebaikan dan } \\
\text { rasa kemanusiaan. }\end{array}$
\end{tabular}

Sumber: Diolah Oleh Peneliti

Banyak jenis hambatan yang dijelaskan dalam mengedukasi masyarakat akan bahaya radikalisme di media sosial ini, sehingga menjadi sulit bagi mereka untuk menjangkau masyarakat apabila mereka yang sudah terpapar, sehingga pemerintah harus bekerja lebih keras untuk mencegah bahkan menghilangkan paham radikalisme atau terorisme di Indonesia ini agar dapat menjadi negara yang memiliki nilai Pancasila sepenuhnya.

Di kondisi saat ini memang kesadaran dan perhatian dari masyarakat sangat penting untuk mencegah bahaya radikalisme ini, karena jika masyarakat yang hadir untuk mengikuti sosialisasi tidak memahami dan mendengarkan maka akan berakibat 
kurangnya informasi dan pengetahuan mengenai radikalisme ini sehingga menimbulkan rasa kurang percaya terhadap apa yang dijelaskan.

\section{Simpulan}

Dari hasil penelitian di atas, penulis membuat kesimpulan sebagai berikut: pertama Radikalisme di media sosial saat ini cukup meningkat sebelum pilpres dan sesudah pilpres karena memang keadaannya cukup panas pada saat itu, dan hadirnya akun-akun buzzer yang turut meramaikan keributan dan membagikan konten-konten yang negatif menjadi salah satu faktor utama radikalisme dimedia sosial ini cukup menjadi perhatiaan.

Kedua, peran yang dilakukan Humas Kominfo dalam para relawan dalam mencegah radikalisme ini sudah bagus dimana mereka terus memberikan edukasi kepada public atau masyarakat akan bahaya radikalisme ini dan terus meng-counter setiap konten-konten radikalisme ini baik melalui media sosial dengan cara membagikan konten-konten positif dan narasi yang damai.

Ketiga, hambatan-hambatan yang dihadapi memang sebagian besar berasal dari pergerakan ormas yang cukup masif dalam memberikan paham radikalisme ini sehingga pemerintah dan juga relawan harus lebih masif juga dalam melawan mereka dalam memberikan edukasi ke setiap masyarakat hingga ke setiap daerah di Indonesia.

\section{Ucapan Terima Kasih}

Peneliti berterima kasih kepada seluruh narasumber baik itu informan kunci maupun informan pada umumnya yang sudah bersedia untuk meluangkan waktunya ditengah kesibukan narasumber-narasumber dan kerjasama yang narasumber berikan dalam memberikan dan membagikan informasi terkait masalah yang diteliti oleh peneliti sepanjang proses penelitian ini berjalan. Ucapan terima kasih juga diberikan teruntuk banyak pihak yang ikut membantu dan memberikan dukungan kepada peneliti dalam proses berlangsungnya penelitian ini dari awal penelitian ini dilakukan hingga selesai. Dan juga peneliti berterima kasih kepada semua dosen serta staf dari Fakultas Ilmu Komunikasi Universitas Tarumanagara yang telah ikut berkontribusi kepada penulis dari awal masa perkuliahan sampai penelitian ini telah berhasil dituntaskan dengan baik.

\section{Daftar Pustaka}

\section{A. Muri Yusuf. (2014). Metode Penelitian Kuantitatif, Kualitatif \& Penelitian}

Bungin, Burhan. (2010). Penelitian Kualitatif: Komunikasi, Ekonomi, Kebijakan Publik dan Ilmu Sosial Lainnya. Jakarta: Kencana

Moleong, Lexy J. (2009). Metodelogi Penelitian Kualitatif. Edisi Revisi. Bandung: PT Remaja Rosdakarya Offset

Nazir, Moh. (2011). Metode Penelitian. Bogor: Ghalia Indonesia

Suprawoto (2018). Government Public Relations. Perkembangan \& Praktik di Indonesia. Jakarta: Prenadamedia Group 
Jefri Handoko, Eko Harry Susanto: Humas Kominfo Dalam Mencegah Bahaya Radikalisme Di Media Sosial

http://belmawa.ristekdikti.go.id/wp-content/uploads/2016/12/Strategi-MenghadapiPaham-Radikalisme-Terorisme.pdf https://databoks.katadata.co.id/datapublish/2019/02/08/berapa-pengguna-mediasosial-indonesia https://tekno.kompas.com/read/2018/12/21/19080077/sepanjang-2018-kominfohapus-295-situs-berbau-terorisme 